\title{
An Anatomy of Cycles in Shipping Industry, 1946-2020
}

\author{
Alexandros M. Goulielmos'1,2 \\ ${ }^{1}$ Department of Maritime Studies, Faculty of Maritime and Industrial Studies, University of Piraeus, Piraeus, Greece \\ ${ }^{2}$ Shipping, Transport and Logistics Department, Business College of Athens, Athens, Greece \\ Email:ag@unipi.gr,am.goulielmos@hotmail.com,agoulielmos@bca.edu.gr
}

How to cite this paper: Goulielmos, A. M. (2020). An Anatomy of Cycles in Shipping Industry, 1946-2020. Modern Economy, 11, 1671-1695.

https://doi.org/10.4236/me.2020.1110116

Received: July 31,2020

Accepted: October 27, 2020

Published: October 30, 2020

Copyright ( 2020 by author(s) and Scientific Research Publishing Inc. This work is licensed under the Creative Commons Attribution International License (CC BY 4.0).

http://creativecommons.org/licenses/by/4.0/

(c) (i) Open Access

\begin{abstract}
The paper provided a help to shipowners-we believe-by determining the duration of cycles, first historically, since 1741, and par excellence since 1945, to 2020, and then mathematically, using Chaos Theory. It was remarkable to find out that both approaches gave the same outcome: shipping cycles lasted 6 years (rounded). We have also explored the possibility to predict a shipping cycle with reference to previous repeated attempts to forecast freight markets, but in this paper, we wanted to see what to suggest to shipowners, when forecasting is impossible-as is! This is in line with most important Greek shipowners, like Mr. G Procopiou, who suggests to ignore forecasters. The paper, however, showed the important corollary that bad times are longer than good times, helping to avoid fatal mistakes as those committed by Sanko shipping of Japan in 1980s. We showed also the more important corollary for businessmen that technology brought shipping cycles closer! We have re-introduced the concept of Joker, rejecting the theory that shipping is a "poker game". To predict the coming of a Joker has not been so far achieved, though we have predicted the start of the 2008 depression using Chaos theory... Ten at least Jokers have appeared since 1951, including the 2019 Pandemic.
\end{abstract}

\section{Keywords}

Business and Shipping Cycles Defined, Their Duration, Historical and Mathematical Counting, Rescaled Range Analysis, Impossibility of Forecasting

\section{Introduction}

Shipping is an industry which suffers from frequent cycles approaching faster as time goes by. Table 1 below mentions 24 shipping cycles since 1741 and till 
Table 1. An historical account of shipping cycles, 1741-2020.

\begin{tabular}{|c|c|c|}
\hline $\begin{array}{l}\text { Cycle } \\
\text { Number }\end{array}$ & Period & Duration (years); main events \\
\hline 1 & $1743-1753$ & 11 Austrian succession War $1740-48$ \\
\hline 2 & $1754-1774$ & 21 \\
\hline 3 & $1775-1791$ & 17 USA war $1775-83$ \\
\hline 4 & $1791-1825$ & 35 \\
\hline 5 & $1792-1813$ & 22 Napoleon's wars \\
\hline 6 & $1821-1836$ & 16 \\
\hline 7 & $1837-1852$ & 16 Average cycle $=\sim 20$ years $(19.7)$ \\
\hline 8 & $1873-1879$ & 7 USA Civil war 1861-1865 \\
\hline 9 & $1880-1886$ & 7 \\
\hline 10 & $1889-1897$ & 9 \\
\hline 11 & $1898-1910$ & 13 \\
\hline 12 & $1911-1913$ & $31^{\text {st }}$ World War \\
\hline 13 & $1921-1925$ & 5 \\
\hline 14 & 1926-1937 & $\begin{array}{l}\text { 12Worldwide depression 1929-1933; trade collapsed 1931-34; } 14 \\
\text { m GRT of ships laid up in } 1932\end{array}$ \\
\hline $14 \mathrm{a}$ & 1939-1946 & $\begin{array}{l}82^{\text {nd }} \text { World war } 1939-1944 \\
\text { Average cycle }=8 \text { years }\end{array}$ \\
\hline 15 & $1945-1951$ & 7 Korean war: early 1950 \\
\hline 16 & 1952-1955 & $\begin{array}{l}4 \text { Vietnam war: 07/05/1954; } 1^{\text {st }} \text { Suez Canal closure: end-October } \\
1956\end{array}$ \\
\hline 17 & $1957-1969$ & $\begin{array}{l}13 \text { Suez Canal reopened April 1957; Cuban war: 1959-1962. } 1967 \\
\text { Six days War Israel-Egypt; Suez Canal } 2^{\text {nd }} \text { closure: } 1967 \text {; oil crisis }\end{array}$ \\
\hline 18 & $1970-1972$ & 3 \\
\hline 19 & 1973-1978 & $\begin{array}{l}6 \text { Oil crisis: end-1973; Yom Kippur war end 1973; Suez Canal } \\
\text { re-opened June-1975; Vietnam war ended (30/04/1975). }\end{array}$ \\
\hline 20 & 1979-1987 & $\begin{array}{l}9 \text { Iranian revolution 1979; Iran-Iraq war (1982); 1981-1987 dry } \\
\text { cargo ships depression }\end{array}$ \\
\hline 21 & $1988-2002$ & $\begin{array}{l}15 \text { Iraq war with Kuwait 1990; } 1997 \text { Asian econ. crisis; Dot.com } \\
\text { crisis } 2001\end{array}$ \\
\hline 22 & 2003-2007 & 5 China's boom \\
\hline 23 & $2008-2013$ & 6 Sub-prime house bank loans \\
\hline 24 & $2020-2021$ & $\begin{array}{l}1 \text { Covid- } 19 \\
\text { Average cycle }=6.9 \text { years } \sim 7\end{array}$ \\
\hline
\end{tabular}

Source: data from Stopford (2009), p. 106.

2020 (280 years). This means one cycle for every $\sim 12$ years. We also calculated cycles' duration, on which we have focused our interest hoping to find a pattern, with a view to pre-identify them. The periods examined here are separated in 3 groups, depending on the main state of propulsion technology: Sails, Tramps and Bulks. 
World suffered also from 9 at least major wars, from which two global, since 1741! Wars are beneficial and harmful at the same time for world shipping: in wars ships are required to transport all kinds of means to those fighting, and for reconstruction afterwards, increasing thus seaborne demand; but also, ships are lost due to war causes.

Our prediction, however, is that local wars will continue... Now an Armenia-Azerbaijan war begun. In fact, our epoch (since 1945) is full of local wars (7 wars at least). Global wars, most probably, will be avoided, as no one will get out alive in a worldwide nuclear war... something well-known by global leaders. World peace is maintained by the fear of nuclear death...

Moreover, the duration of shipping cycles fell over 3 technological periods: from $\sim 20$ years to $\sim 7$ on average (Table 1 ). This suggests that technology-the factor which has changed, and no doubt, affected cycles, made the duration of recessions and depressions shorter...! Of course, it is useful to know that cycles now are coming sooner to get prepared and react properly (Goulielmos, 2020). In future, a shipping cycle may be even shorter, as technology continuously improves... Shipowners have to learn to live with cycles as Greeks learned to live with earthquakes and... COVID-19!

Our reference to technology is to that of building ships, including their mean of propulsion, speed, unloading/loading means, fuel etc., and how fast large and faster ships, or sophisticated ones, can be built! Can we blame shipbuilding for delivering ships to shipowners fast, even 1 say within 3 months? Or have we to blame shipowners for over-ordering ships and demanding to get delivery of them as soon as possible to get advantage of the rising market?

There are also involved "economies of scale"-a matter again of technology-by which supply can increase by leaps and bounds! To avoid a possible misunderstanding, economies of scale depend on the existence of an analogoussized demand, called "shipment"1 or unit-load, which determines the maximum size of a vessel among other factors. Passenger ships are built marginally larger than the estimated demand per voyage to face a future increase.

To understand the magnitude of errors which can be committed by shipowners during a depression, we take the one between 1981 and 1987, where $\sim 48 \mathrm{~m}$ dwt of tankers were ordered, $\sim 221 \mathrm{~m} \mathrm{dwt} \mathrm{were} \mathrm{laid-up} \mathrm{and} \sim 93 \mathrm{~m}$ dwt were scrapped, out of an estimated fleet of $400 \mathrm{mdwt}$... A great waste of valuable resources, no doubt! This demonstrates sadly the failure of shipowners/and maritime economists to predict cycles!

\section{Aim and Organization of the Paper}

The purpose of this paper is to calculate the exact duration of shipping cycles, first historically, par excellence between 1945 and 2020, and then mathematical-

${ }^{1}$ The maximum size of one shipment is a rather synthetic outcome depending mainly on the timing of individual demands grouped together, the storage facilities of the importers, delivery times to those ordered, common unload areas, capacity of storage facilities etc. 
ly. Also, we want to remind reader of the reasons that caused those cycles. Analysis here is based on cycle's definition provided by economic theory (i.e. from a good economic dictionary). We will refer also to a paper, which tried to forecast shipping cycles to see if this was possible before working on the assumption that forecasting is impossible in maritime economy... held also by the most powerful Greek shipowners.

In the shipping (game) $)^{2}$, we believe, that one at least... Joker is always in the pack of cards.

The paper is organized in 4 parts, after literature review: Part I, deals with the definition of business and shipping cycles; Part II, presents the 4 cycles in freight markets of tankers and dry cargoes, between 1947 and 2020, in an historical analysis; Part III, deals with the cycles in nonlinear Time Series; Part IV deals with the "impossibility theorem" of forecasting shipping cycles. Finally, we conclude.

\section{Literature Review}

Research on cycles started in UK in 1815 (Stopford, 2009: p. 96)! Moreover, Schumpeter (1954) (1883-1950) noticed that the world "cycle" was used first by the English economist Petty W (1623-1687) in 1662. Schumpeter (1954), moreover, related cycles to technology, approach adopted also by Stopford (2009). Observers at old times came to the conclusion that crises formed part of a wave-like mechanism, acting on economy. They started then to call them "cycles" though a wave is not cyclical... but re-occurring.

Cournot (1927) (1801-1877) distinguished cycles, in 1838, as those lasting 60 years (long cycles), in seasonal, and in short lasting 5 - 10 years. In shipping, tanker demand e.g. is par excellence seasonal among other things as in severe winters assumes naturally higher levels.

Economists were not in agreement about a unique cause of cycles. A voluminous literature (494 pp) published in 1950 (American Economic Association, AEA, 1950), classified cycles in 12 different main theories! There, 449 famous authors are mentioned ${ }^{3}$, including Keynes, with one or more publications. After 1950, we believe, the subject of business cycles attracted a lesser interest, and theories of growth of GDP took its place as more important and also novel.

Modern economists were brought-up as we did with Keynes' General Theory in 1936, triggered by the 1929-1933 depression we believe, they were occupied or rather fascinated by the task to transforming Keynes "General theory" into a long run dynamic growth theory, (e.g. the "Harrod-Domar" growth model in

\footnotetext{
${ }^{2}$ Martin Stopford (2009), by the way, was wrong to support the theory that shipping game is one resembling poker!

${ }^{3}$ All famous economists dealt with trade cycles before 1950: Cassel G; Clark J M; Galbraith J K; Haberler G; Hansen A H; Harrod R F; Hawtrey R G; Hicks J R; Jevons H S; Kaldor N; Kalecki M; Keynes J M (12 papers); Kuznets S S; Lange O; Leontief W W; Machlup F; Robinson J; Samuelson P A; Tinbergen J; Young A A and others. Tinbergen (1903-1994) has dealt also with maritime subjects and shipbuilding cycles. Koopmans T (1910-1985), another maritime economist, criticized Tinbergen for assuming a peak period equal to a trough one in 1940s!
} 
1940s was characteristic). Moreover, growth is something that all political parties agree, unlike "distribution of income".

Stopford (2009; chapter 3) gave a detailed presentation of shipping cycles, and in addition, recorded the freight rates of dry cargo ships, and their cycles, since 1741 (Figure 1). Table 1, moreover, has summarized these 22 cycles and updated them to 2020 .

As shown, 22 cycles recorded along 259 years, till 2007. The "Wind/Sails period" lasting till 1871 , i.e. 130 years, since 1741 , gave a cycle duration of $\sim 18.5$ years on average over 7 cycles. Interesting is the fact that after 1945, and till 2020 , only 10 shipping cycles occurred over 76 years, reducing ${ }^{4}$ the average duration of cycles to 7.6 years from $\sim 18.5$ !

Stopford (2009) argued that from 1945, and for 50 years, the mechanization of "bulk" and "liner" shipping, using also bigger" ships, and more efficient cargo-handling technology, produced a fall in real freight rates. This is quite true that efficiency came through economies of scale and better mechanization in ports and stronger unloading-loading means in both ships and ports. This is so because time everywhere is the secret factor in shipping to the extent that "economies of time" is a very important chapter.

Summarizing, the problem of cycles occupied economists very early, since 1600s. Schumpeter (and Stopford) were first to connect cycles with technology. We, connected, cycle's duration with technology... To predict the coming of a

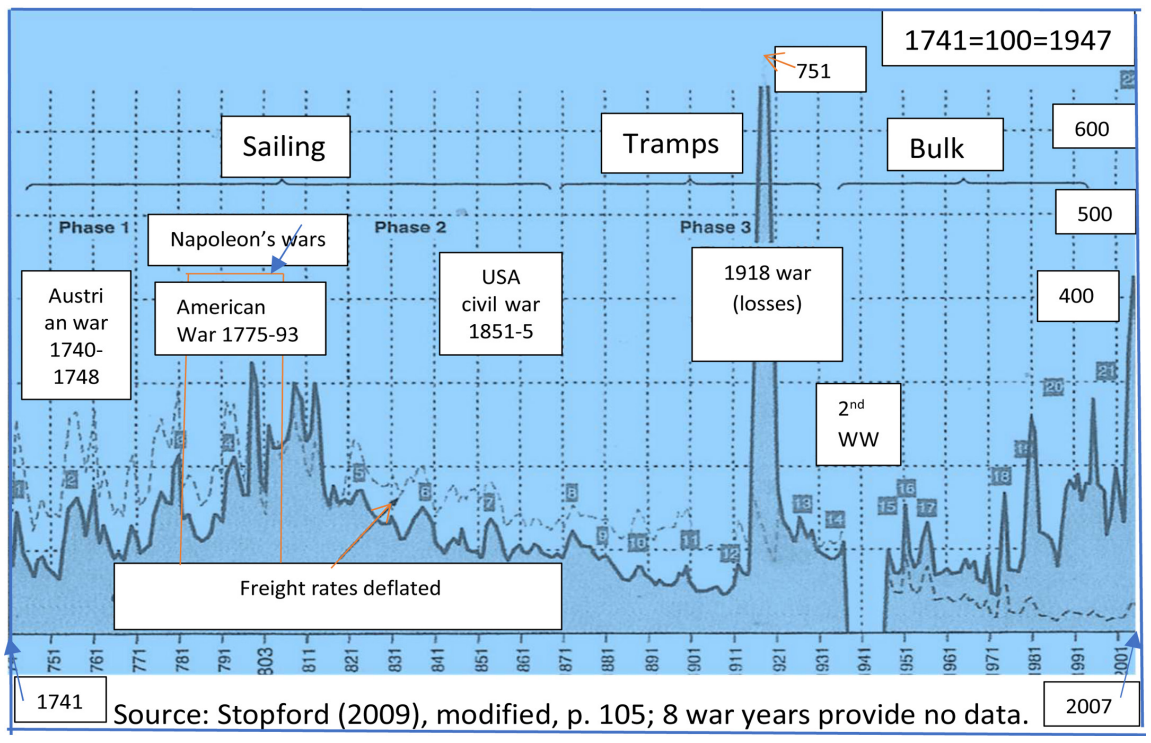

Figure 1. 22 shipping cycles of freight rates of dry cargo ships, 1741-2007. Source: Stopford (2009), modified, p. 105; 8 war years provide no data.

${ }^{4}$ If we exclude the 2008 depression and the 2020-Pandemic.

${ }^{5}$ Ships are used to transport cargoes in bulk like coal, grain, fertilizers, iron ore, oil etc.

${ }^{6}$ Ships transporting products coming from manufacture and craft industry suitable for economic development. These ships are e.g. container-ships.

${ }^{7}$ Shipowners and Onassis discovered that bigger ships attain a lower cost per ton of cargo. Many costs including building cost fall on average as they do not increase faster than the increase in carrying capacity (dwt). 
cycle proved to be a hopeless endeavor for centuries. Its duration is also not pre-known. These are 2 points where forecasters have failed.

Stopford (2009) described the above situation as the one where 30,000 shipowners play "poker"; we insist that the situation is not one of playing poker, but one of including a "Joker" in the pack of maritime cards. Joker manifests, after all, the "Free Will" of businessmen.

Greek shipowners realized the above situation and invented a win-win strategy (Goulielmos, 2020), that always works in their benefit, and ends to a higher competitive advantage. Surely, perfect timing in decision making is not accomplished by all humans... but Greeks achieved $86 \%$ accuracy in attempting it...

\section{Definition of Business and Shipping Cycles}

To give an idea of how shipping cycles are created, we present Demand (=seaborne trade) (Figure 2), which clearly fell in 1974-5 for the first time, due to the "Yom-Kippur war" between Israel and Egypt in October 1973. This caused the $2^{\text {nd }}$ and longer closure of the Suez Canal, and brought a structural depression till 1988, hitting par excellence tankers, with the only exception: year 1979. Tankers hit as they were by majority passing Suez Canal. The 1981-1987 depression, which started in 1979 for tankers, was due to the oil price increase, enforced by OPEC at that time.

As shown, it is clear that the fleet does not follow always trade, as in 1950-1964 and in 1975-1995. Shipowners over-ordered ships during peak periods, so that ships to be in numbers above of what was required (blue line above red one).

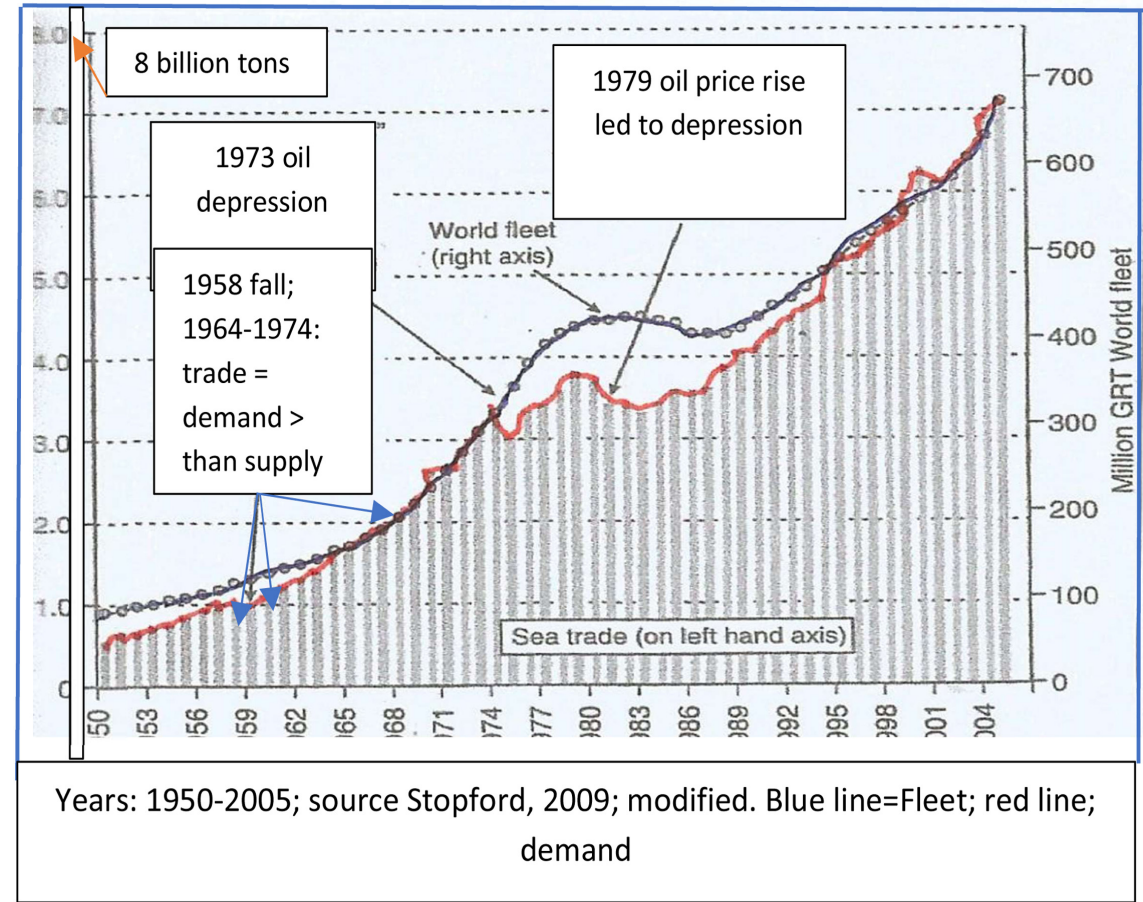

Figure 2. Global trade and world fleet, 1950-2005: the 2 main components. 
A cycle, (called also business or trade), are 2.5 time periods of fluctuation (say in the level of economic activity, proxied e.g. by GDP), of a regular pattern with an expansion followed by a contraction, and again by an expansion... (a definition modified slightly by us from that found in Pearce, 1992).

Economists conceived trade cycles as regular, excluding thus all sudden appearances, caused, e.g. by wars $(1914 ; 1939)$; by collapses of Stock Exchanges (1929); by collapses of USA Banks (2008); and by a Pandemic (2020; Covid-19)! The reason was that economists did not like to take them as dealing with random events ${ }^{8}$, like the weather. But are cycles random manifestations or are representations of deterministic chaotic time series?

The trade cycle, diagrammatically, is drafted as follows (Figure 3 ).

As shown, a cycle has a peak: at B, and a trough: at D. Cycle's period is: either from $A$ to $E$, or from $B$ to $F$. A cycle starts from the trend line and returns to it (A-E). As shown, a cycle retards the uprising of GDP. This can be seen, as during the movement of GDP from A to $\mathrm{E}$, had first to pass from $\mathrm{C}$ to $\mathrm{E}$, before reaching $\mathrm{E}$, and thus delaying. In other words, if GDP could avoid part $\mathrm{CE}$, and the time required to pass it, then GDP could reach faster E, say in $1 / 2$ time. The trend, however, may be downward as well The cycle is not really a full one, but a sum of 2 halves... Cycle's amplitude is BG.

What is wrong, and dangerous, however, is to assume $\mathrm{AC}=\mathrm{CE}(\mathrm{BD}=\mathrm{DF})$. In other words, expansion and contraction phases are not equal... In shipping we know very well that good times are much shorter than bad times!

\subsection{The Shipping Cycle}

As shown (Figure 4), the shipping cycle, $\mathrm{CE}$, is drawn the same way as business

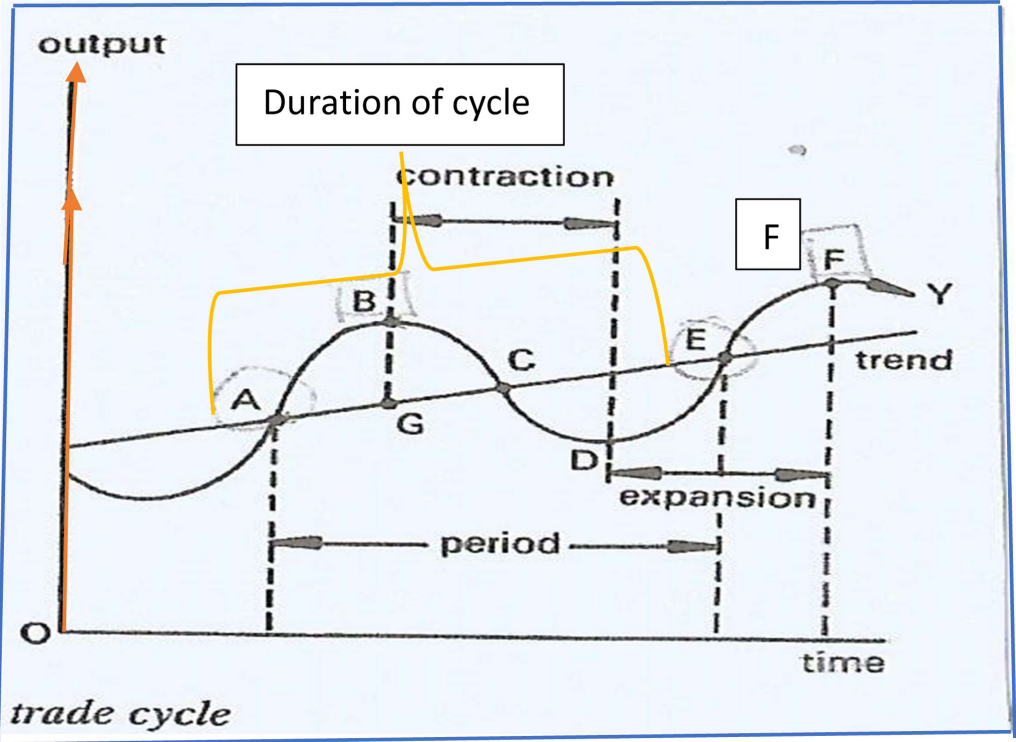

Figure 3. The trade cycle. Source: modified from that in Pearce, 1992.

${ }^{8}$ Economists convinced to deal with cycles when they saw them to return! They did not like to take them as dealing with "Winds and Waters"! 
cycle. Wrong is also here that: CG = GE! The dramatic implication of drafting a peak as equal to a trough, is mentioned below, in the case of "Sanko Shipping Company of Japan" in 1980s. The variable that interests par excellence maritime economists is freight rate and not so global GDP.

A shipping cycle, however, unlike business one, has clear causes: 1) a fall in the seaborne trade (demand) and/or 2) an increase in ship space (supply), cause a fall in freight rates, so that, for a short, or a long time, ships earn nothing above their cost... This leads ships to lay-up, (temporal removal from market), and eventually to scrapping (permanent removal from market), as the revenue from transporting a unit of cargo is less than her ${ }^{9}$ cost.

As shown by Goulielmos (2020) demand and supply move independently one from the other! This disharmony causes the shipping cycles. Changes in demand seem to be the initiating factor, and supply follows. Small changes in demand (expressed in billion tons) cause great changes in supply (expressed in million tons-dwt), a par excellence nonlinear case... Crucial role play of course time and developments that may occur between "deciding to build a ship" and get deliver of her by her owners.

\subsection{Recessions versus Depressions}

We may distinguish recessions from depressions. A recession is a situation where 1) a fall in demand (seaborne trade), and/or 2) an increase in supply of ships, are small, so that the fall in freight rates that follows, is also limited and lasts a short time; i.e. "a low amplitude case"; this means a small \% of ships in lay-up and also a more limited tonnage in scrapping.

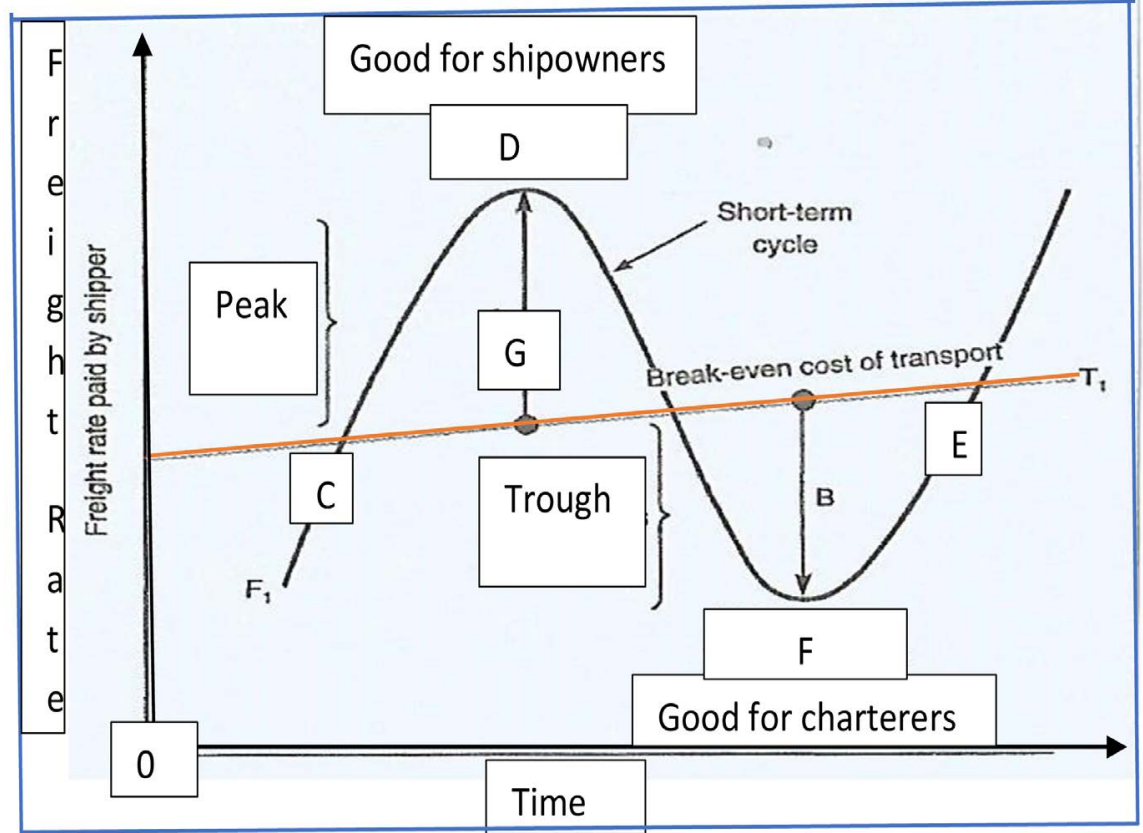

Figure 4. The shipping cycle. Source: modified from that in Stopford, 2009: p. 102.

${ }^{9}$ In English a ship is a female. 
To have a feeling of the magnitudes involved in cycles, trade in the 1929-1933 depression fell $26 \%$; laid-up tonnage ( $14 \mathrm{~m}$ GRT) reached $21 \%$ of global fleet; $2^{\text {nd }}$ hand prices from $£ 280,000$ dropped to $£ 5000$ ! But these percentages etc. should not be taken as fixed ${ }^{10}$ as these may not be repeated in future.

In a shipping depression, the variations naturally are greater, and its duration longer, vis-à-vis a recession: the 1929-1933 depression e.g. lasted 8 years (to 1936); the 1981-1987 dry cargo depression lasted 6 years, and the 2008-2013 lasted 5 years, or so, while the COVID-19 depression will last 1 year (presumably: 2020-2021). The time a good market lasts is not standard, and it depends on a number of factors; similarly, the time that a recession or a depression lasts is also unknown. We have to remember these facts.

Shipowners know (feel) when a recession/depression happens, and thus, they cut costs down, starting from crew costs (Niarchos), but they do not know how long a crisis is going to last, and they know nothing about the time when it will come...

In shipping, there are, of course, mechanisms which are expected to "bring" equilibrium: when freight rates increase, owners order ships, but their delivery takes time, as mentioned, given the time for the "decision to order and for construction”, securing finance etc.; when freight rates fall, shipowners create a provisional equilibrium (lay-up) and a permanent one (scrapping), if a recession becomes a depression.

But while a lay-up decision is relatively a fast one, a scrapping decision, as more serious and decisive, needs a number of years ( $3-4$ years) at a cost of course. Shipowners are optimistic persons, and they are always hoping. Hope dies last, they say...but it cannot avoid final death!

\subsection{Peaks versus Troughs}

Stopford (2009: p. 106) calculated the duration of shipping average peaks as equal to 3 years (1947-2007), and the duration of average troughs as equal to 5 years. Short booms mean that supply responded fast to a higher demand. It also means that long time charters should be preferred...

To restore the truth in relation with the actual duration of the two half-circles of 1 shipping cycle, we have constructed the following (Figure 5).

As shown, the time that 2 troughs last, are longer than the timelpeak lasts. Also, one trough may be deeper than another. This pattern is indeed real for shipping cycles. Stopford (2009: p. 107) counted troughs between 1947 and 2002 for dry cargoes, the longer being the one in 1958-1969, lasting 12 years! The peaks between 1947 and 1997, lasted 2.71 years on average, the longer being the 1988-1997 one, lasting 10 years! Let us see what maritime history has to tell us!

\footnotetext{
${ }^{10}$ Our experience showed that there are no rules about shipping crises like: that only small ships are hit; or, only older ones; or, only tankers or only dry cargoes, and so on. Every ship has its own supply and demand, which determines her freight rate over her route given her size, age, flag etc. We saw cases where old ships prospered; also, smaller ones prospered... and vice versa.
} 


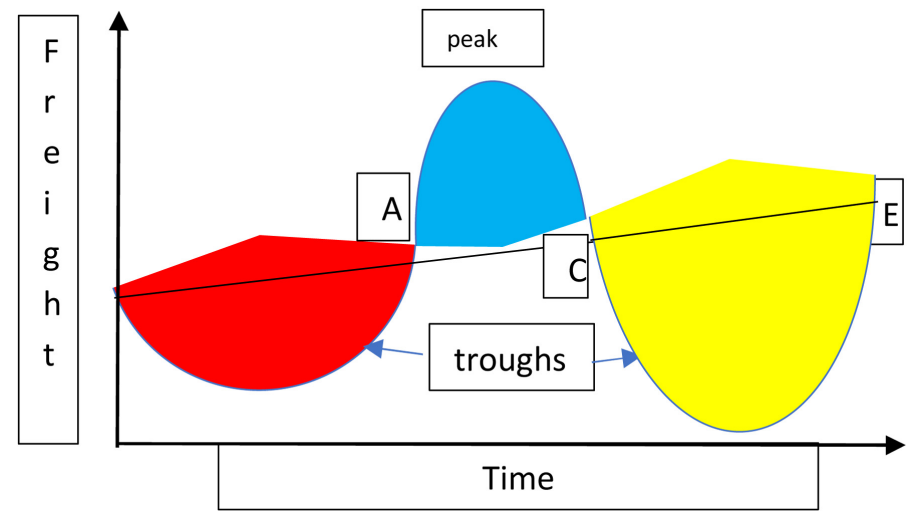

Figure 5. Real peaks and troughs in shipping. Source: author.

\section{The 4 Cycles in Freight Markets, 1947-2020, an Historical Analysis}

\subsection{The $1^{\text {st }}$ Cyclical Period, 1947-1962 (16 Years)}

\subsubsection{The Dry Cargoes' Cycle, 1947-1962}

As world markets re-opened in 1945, dry cargo freight rates increased and continuously rose till 1947 ( $1^{\text {st }}$ peak) (Figure 6); 1947 was a positive year. After $2^{\text {nd }}$ WW, it was natural nations to begin reconstructions, so demand (seaborne trade) was intense soon after the $2^{\text {nd }}$ global war stopped. Soon, however, a falling trend started, and the pessimism among ship-owners returned (1948-9) due to over ordering.

The $1^{\text {st }}$ postwar cycle for dry cargoes is shown in Figure 6. The cyclicality of freight rates is clear. According to the definition of the cycle, given above, the cycle started in 1951, (caused by Korean War), at A and ended in 1956 (after 6 years) at B. Here we identified two short-lived peaks: 1951 and 1956, when Suez Canal also closed for 6 months (in end-1956). Canal's closure multiplied demand for ship space, as distances increased overnight...

The increase in rates, due to lack of supply, and/or a rise in demand, given distances, induced a higher shipbuilding production, and upon its delivery, freight rates fell... Ships delivered in greater numbers than needed! Thus, the main causes were: "Korean war" and " $1^{\text {st }}$ Suez Canal closure", which both created a greater demand, and an opportunity for economies of scale; while over-ordering caused a greater supply. These 3 events consisted also the 3 appearances of the Joker.

Let us remember the Jokers that have appeared during this period.

The Korean war did not last long. The more important event for shipping was the $1^{\text {st }}$ Suez Canal closure, but this was also short (6 months). Anyway, this closure induced different predictions by shipowners, where some believed that the Canal will not open soon (Onassis A, but not Gratsos C.), but it did. Moreover, economies of scale had naturally this period a great impact on supply.

\subsubsection{Tanker Freight Rate Cycle, 1947-1963}

The tanker freight rates (Figure 7) had also a cyclical pattern, between 1947 and 


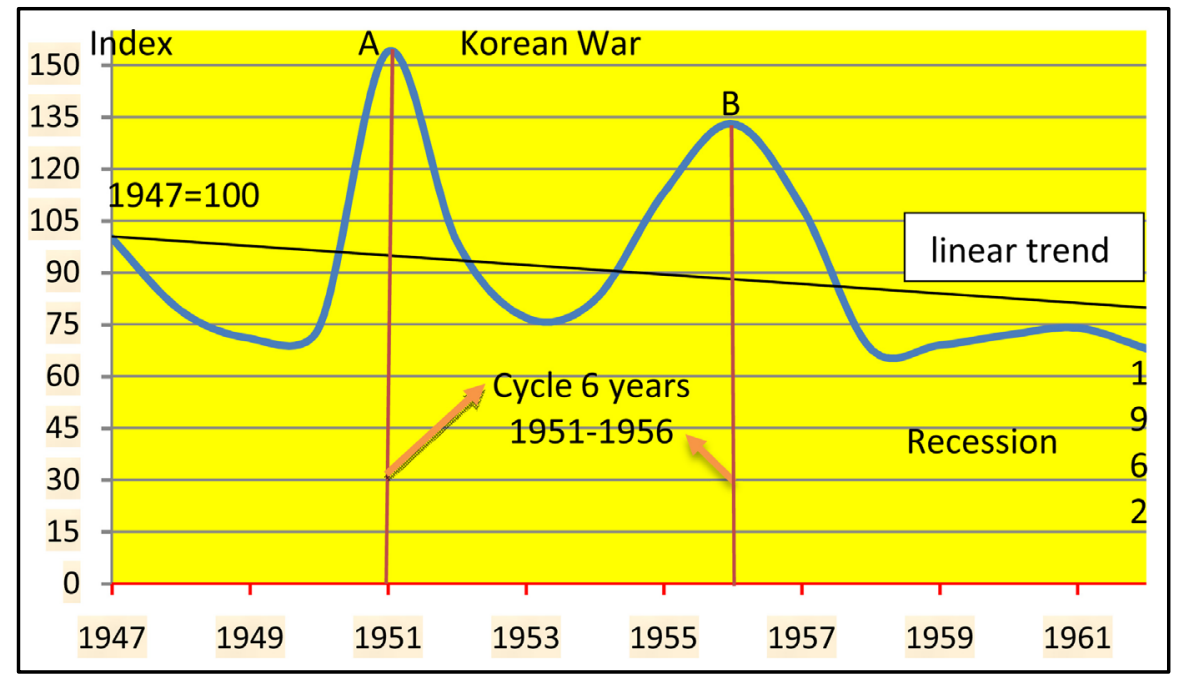

Figure 6. The freight rate market of $d r y$ cargoes, 1947-1962. Source: author; data from Stopford (2009).

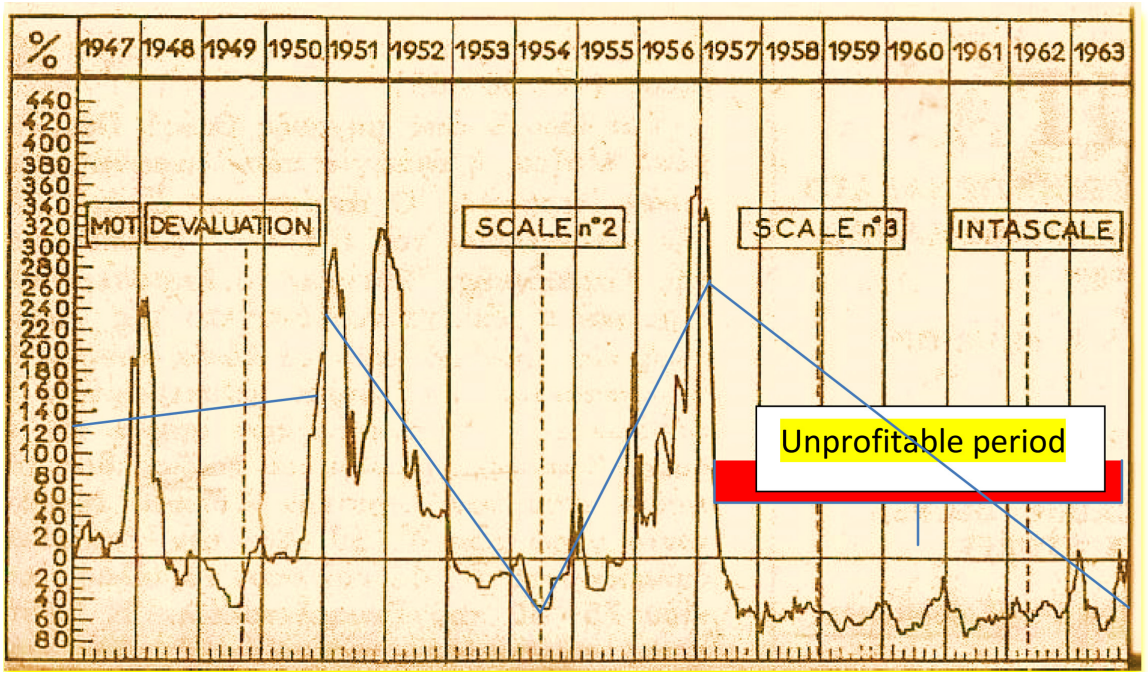

Figure 7. Tanker freight rates, 1947-1963. Source: Scale indices; notable is the low levels in 1957-1963 (7 years); the tanker index MOT depended on Sterling devaluation.

Table 2. The non-shipping events occurred between 1947 and 1962.

\begin{tabular}{cccc}
\hline Event & Year & Event & Year \\
\hline $\begin{array}{c}\text { Korean War: } \\
\text { Joker 1 }\end{array}$ & From early 1950 to & Suez Canal ${ }^{\text {st }}$ closure: & Joker 2 \\
Suez Canal & 1951 & & \\
re-opening: & & & \\
Joker 3 & April 1957 & & \\
\hline
\end{tabular}

Source: Author.

1963 (Table 2). In fact, we identified 4 cycles: 1947-1950 (4 years); 1951-1954 (4 years); 1954-1957 (4 years) and 1957-1963 (7 years).

The demand for tanker ship space re-appeared strong, (at the end of 1950), 
but the orders for new ships stopped soon thereafter. When the memory of $2^{\text {nd }}$ WW started to faint-out, Korean War (1950-1951), revived it, creating a "stock-building panic. Between 1945 and 1950, freight markets stabilized, while between 1951 and 1952 peaked. Seaborne trade increased by 16\%, but this was short (12 months), followed also by certain import restrictions. These factors led to the laid-up of ships by 1953 . The crisis deepened, covering also the $1^{\text {st }}$ half of 1954. Freight rates peaked in 1956 (due to the $1^{\text {st }}$ Suez Canal closure).

\subsection{The 2nd Cyclical Period in Freight Markets, 1963-1975 (13 years)}

\subsubsection{Dry Cargoes Freight Rates Cycles}

The spot dry cargoes market during this period moved into a recession for 3 years (1970-1971-1972). The owners, who could predict, signed (long term) time charters (Figure 8).

As shown (Figure 8), freight rates for dry cargo ships, fluctuated below 100 units $(1947=100$ index $)$ till 1972, when a recession emerged, extending to 1975, which interrupted by 2 prosperous years: 1973 and 1974. There were 2 peaks in 1970 and in 1973-1974, coinciding with the 1st "Oil crisis" in 1973-1974. The 2 cycles started in 1967(at A) and ended in 1970 (4 years) (at B) and in 1970 (at B) till C in 1974 (5 years). Dry cargoes ships resisted till 1974, and the small cargo ships till 1975.

\subsubsection{Tanker Freight Rates Cycles, 1964-1972}

In tankers, years 1967 and 1970 made the whole good difference (Figure 9). The peaks occurred in 1967 and in 1970. While in 1973 the oil crisis in Oct. took place.

As shown, tanker freight rates, after a long period of low levels from 1957 to mid-1967 ( 10 years), showed a cyclical pattern. However, the Yom-Kippur

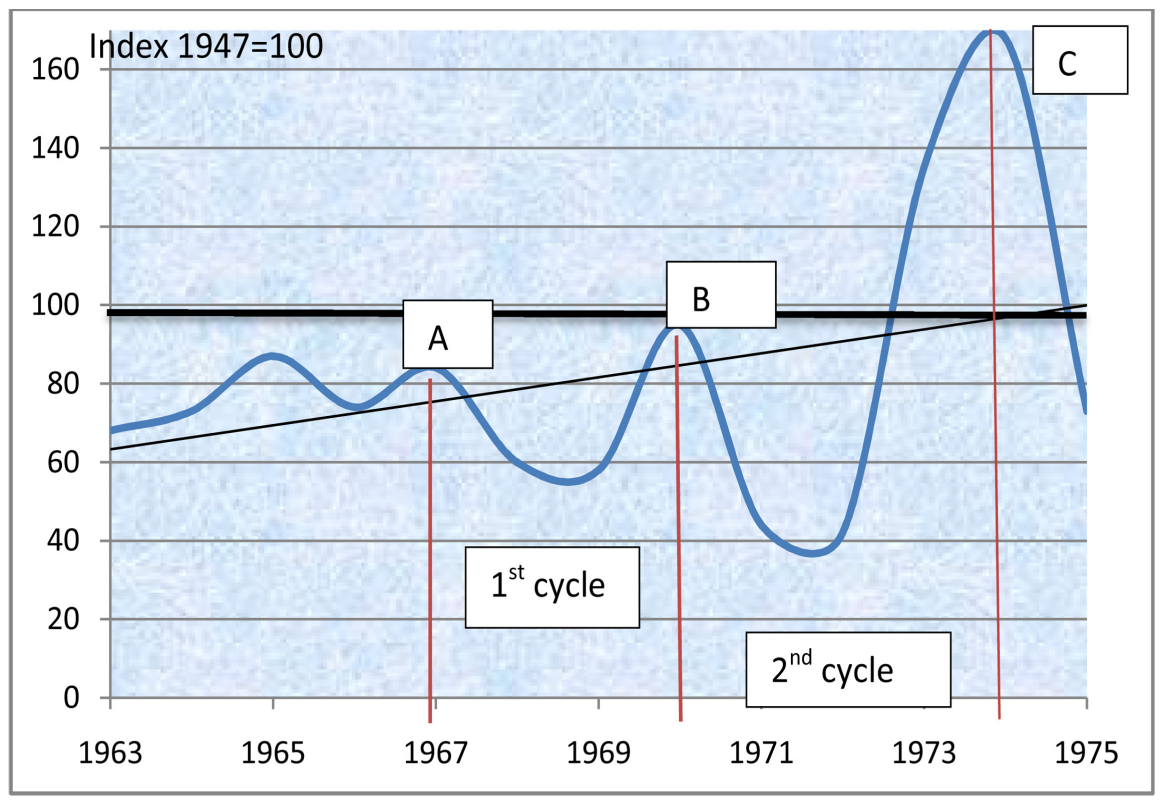

Figure 8. Dry cargo freight rates, 1963-1975. Source: author; data from Stopford (2009). 


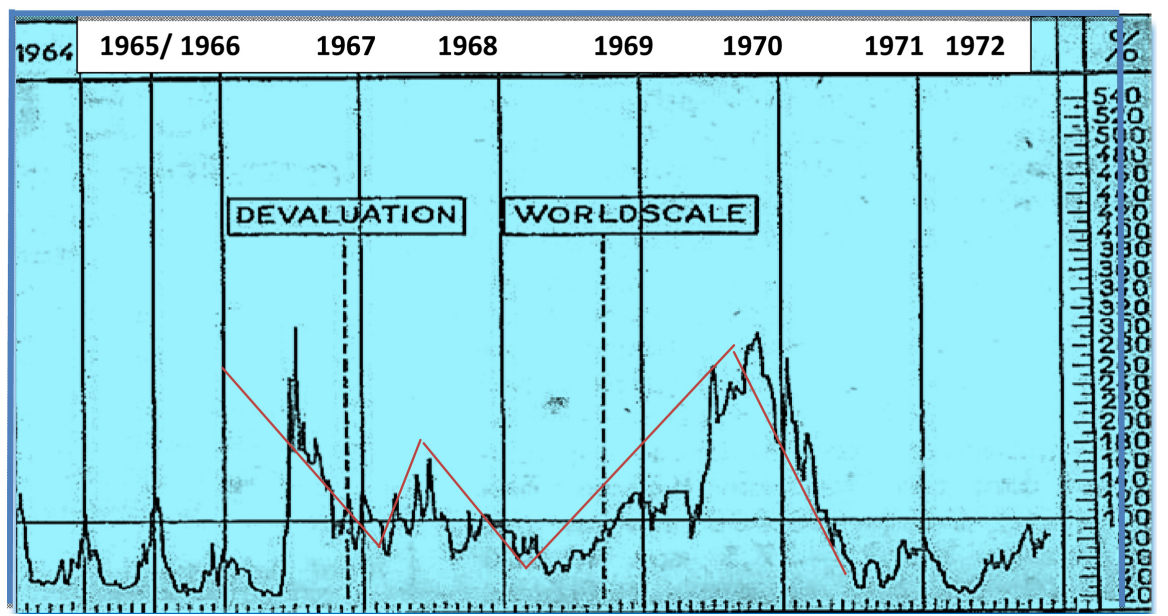

Figure 9. Tanker freight rates index, 1964-1972. Source: World scale index; modified.

war" in 1973 collapsed the tanker market. The Joker ${ }^{11}$ appeared in the form of a war. The cycle started in 1967 and ended in 1970 (4 Years).

\subsection{The $3^{\text {rd }}$ Cyclical Period, 1976-2007 (32 Years)}

\subsubsection{The Sanko Shipping Company of Japan}

The 1981-1987 depression was serious, lasting 6 continuous years, and it was also deep. The depression "should" last 4 years, not 6, but "Sanko shipping company of Japan", comprehending shipping cycles wrong, embarked in an extensive shipbuilding program of several million dwt (Stopford, 2009: p. 126; Couper, 1999: p. 37).

Freight rates were depressed par excellence in 1983-1984. Certain owners, however, placed a large number of orders for bulk carriers. This was an act started by Sanko, which secretly ordered 120 dry cargoes ships of about 30,000 dwt each, or $3.6 \mathrm{~m} \mathrm{dwt} \mathrm{in} \mathrm{total!} \mathrm{This} \mathrm{company} \mathrm{lost} \mathrm{money} \mathrm{by} \mathrm{investing} \mathrm{massively}$ and exclusively in 50 or so tankers certain years ago. Then it decided to turn to bulk carriers so that to obtain the profits required to make-up losses from tankers!

The popular saying that: "do not put all your eggs in one basket" became true as Sanko was only a tanker owner. As secrets cannot be kept in shipping, Greeks, Norwegians and others rushed also to order ships after Sanko. This enormous and unexpected supply depressed dry cargo markets further ${ }^{12}$ and for 2 more years and retarded its recovery till $2^{\text {nd }}$ half of 1987.

To the above outcome a number of other events contributed: 1) Shipowners had accumulated large cash reserves from the 1980 boom. 2) Banks had also large deposits of "petrodollars", as called, available to finance shipowners. 3) Ships were cheap due to overcapacity in shipyards. 4) Tankers were excluded

\footnotetext{
${ }^{11}$ Like the appearance of a joker in a pack of cards, also a sudden, unexpected, appearance of an event in shipping markets, changes the normal pre-existing movement of freight rates either up or down. We tend to believe that the arrival of the joker is unpredictable...

${ }^{12}$ Stopford mentions a similar case also in 1905-1906.
} 
from orders due to their crisis. 5) New fuel-efficient ships emerged as a reaction to the substantial rise in oil prices after 1973. 6) The favorable yen/\$ parity favored building ships in Japan.

But crucial for Sanko was its belief that a shipping cycle lasts definitely 4 or 6 years, as used to be in the near past; thus 1984 was going to be the next cyclical move up (1981-1982 or 1983 down; 1984-1985 or 1986 up), and thus they ordered in 1983 to get delivery in the considered uprising of the market in 1984-!

The above logic was right, but its basics were wrong. The basics were real cycles duration! Also, the high order of more than $3.6 \mathrm{~m}$ dwt by Sanko alone, increased supply of ships, so that the already depressed market to fall in an even lower level. The index (BFI-Baltic Freight Index) fell below 560 units.

The shipping cycle has no symmetry up or down! ...This is the reason that we insisted to say above that peak times are shorter than trough times, and they have to check market every time. Moreover, a substantial rise in supply will definitely affect freight rate, given demand and distances. Sanko forgot the famous rule that supply and demand for ship services determine price...

\subsubsection{Dry Cargoes Freight Rates, 1976-2007}

Freight rates in dry cargo market for 1976-2007 are shown (Figure 10). Three cycles can be singled-out (of 9, 6 and 9 years duration respectively).

As shown, the dry cargoes freight rates boomed, with peaks in 1980, 1995, 2004 and 2007; but the real fortunes were made after 2003 \& till end-2008!

The historical events that took place were (Table 3).

In tankers, 1979 was exciting; 1988 was a good year; 1989 even better; 1996-1997 were, comparatively, improved; 2000 was extra prosperous, as well 2004; in 2007 freight rates peaked high for the first time. This period is a golden one for shipowners, we believe, and is related to the growth of China, destined

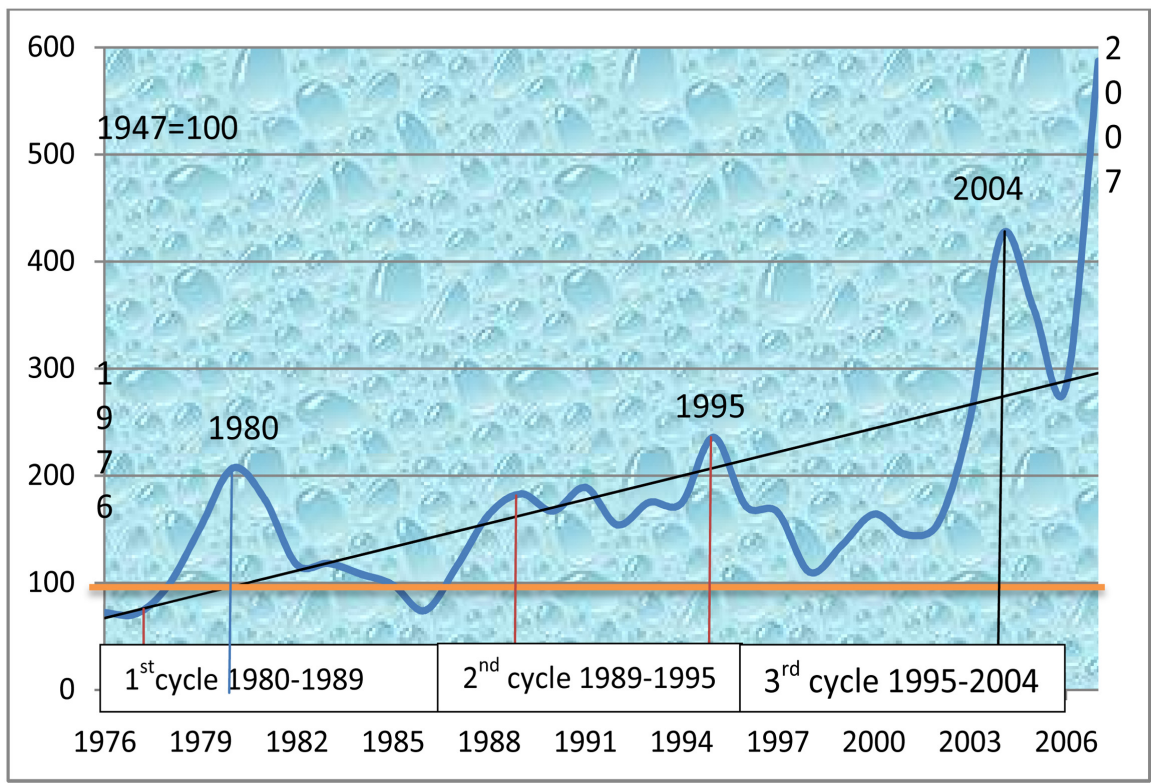

Figure 10. Dry cargo ships freight rates, 1976-2007. Source: data from Stopford (2009). 
Table 3. Main events in 1979-2008 for tankers and dry cargoes.

\begin{tabular}{cccc}
\hline Event & Year & Event & Year \\
\hline $\begin{array}{c}\text { Iranian revolution } \\
\text { Joker 4 }\end{array}$ & 1979 & $\begin{array}{c}\text { Kuwait war } \\
\text { Joker 5 }\end{array}$ & 1990 \\
$\begin{array}{c}\text { Iran-Iraq war } \\
\text { Joker 6 }\end{array}$ & 1982 & $\begin{array}{c}\text { Asian crisis } \\
\text { Joker 7 } \\
\text { China's boom } \\
\text { Joker 9 }\end{array}$ & 1997 \\
$\begin{array}{c}\text { Dot.com crisis } \\
\text { Joker 8 }\end{array}$ & 2001 & 2003-2008 \\
\hline
\end{tabular}

Source: data from Stopford (2009).

to be terminated by end-2008 depression, consolidation and COVID-19 pandemic in 2020.

This permits us to pre-tell that as soon as China recovers, and global trade recovers also, shipping will have many brighter days again. Surely, China will become soon the $1^{\text {st }}$ global maritime nation...

One must take into account that a long prosperous period of extremely high freight rates, like the one after 2003, (to end 2008), made shipowners capable with abundant monetary means to seek opportunities, which everybody admitted by 2016. Crisis (like the one in 2009-2013) definitely brought greater opportunities for investing!

As a corollary, we may say that shipping firms must create reserves from current profits to exploit opportunities, (only at rock-bottom prices), and overcome a depression... A strategic dividend policy has to be adopted and a correct depreciation policy. The higher the depreciation rate, the more savings are realized by the company for new investments. Shareholders can be satisfied to get a dividend for their share-capital above current deposit rates offered by banks, which any way are low, or even negative during and after 2008. So, shipping companies do not have to distribute their entire profits to shareholders, obtained in prosper times, to get prepared for the rainy days of recessions/depressions.

During COVID-19 ships in 2020 had problems to carry-out repairs in China, and other areas, where quarantines were in force; and also, they could not send or repatriate crews to/from quarantined ports...

People working at home and avoiding to be were their colleagues were, as used to be, (tele-working or working from home), cut down consumption of fuel for private cars. All kinds of transportation hit, and par excellence air industry. Tourism halted; and the only trade was for specific medical supplies and... oranges supposed to beat virus. Many countries closed their borders or opened them with rules. COVID-19 is nothing but another Joker... No one pre-saw its coming... and no one knows its final departure after killing $1 \mathrm{~m}$ humans by end Sept. 2020.

Interesting is that COVID-19 reduced to 2095 the global millionaires (58 fewer ones in $08 / 03 / 2020$ ) and made them $51 \%$ poorer. Shipowners held the $74^{\text {th }}$ position (K M Kuehne); $141^{\text {st }}$ (Fredriksen J); 208th (R. Saade) and 230st (G Aponte) (Forbes announcement). Cruising hit decisively as virus could be found 
in passengers, but also in crew!

\subsection{The Cyclical Period, 2008-2020 (13 Years)}

The impact of the last depression starting at the end-2008-beginning 2009, is shown below (Figure 11) concerning its impact on the fleets of the 11 top-global maritime powers.

Greek owned fleet from mid-2008 to mid-2009 fell; in 2016 Greek-owned fleet had also a slow move up. Other maritime nations increased their fleet. Greece subsequently more than doubled its fleet by 2018. Japan was unaffected from the global depression till mid-2012; then assumed a slower growth, between mid-2012 and 2018. China was almost unaffected from 2007 to mid-2014 (71/2 years), then it doubled its fleet from 2011 till mid-2014 (in 31/2 years!).Then Chinese fleet had a great fall losing about $50 \mathrm{~m} \mathrm{dwt} \mathrm{(2014-2015)!} \mathrm{This} \mathrm{perhaps}$ was the result of nation's seaborne trade consolidation, following its round 7\% $8 \%$ growth rates p.a. in the past. China's fleet fell back from mid-2014 to mid-2017. Germany fell back earlier than China, from mid-2009 to 2010, and again from 2012 to 2018.

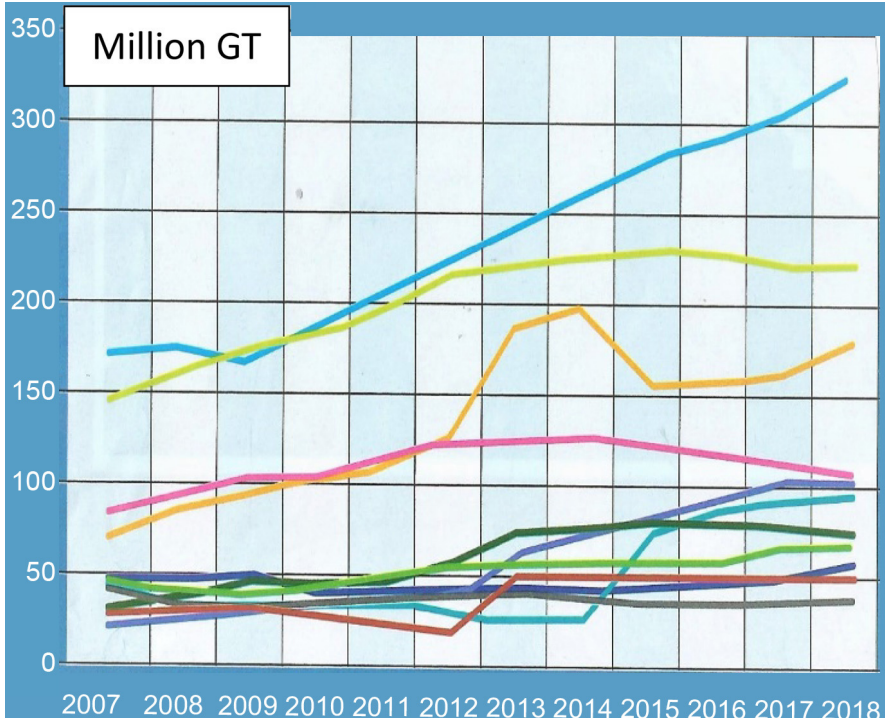

\begin{tabular}{l|l|}
\hline & Greece \\
& Japan \\
\hline & China \\
\hline & Singapore \\
\hline & UK \\
\hline & USA \\
\hline & Korean Rep. \\
\hline$\quad$ Germany \\
\hline & Denmark \\
\hline & Hong Kong \\
\hline & Norway \\
\hline
\end{tabular}

Figure 11. The fleets of the 11 most powerful sea powers in GT, 2007-2018, for ships greater than 1000 GT-in million GT. Source: UNCTAD, issues of the Review of maritime transport, 2007-2018 and Greek press vima. 
Notable, certain areas have grouped now in single markets like e.g. EU. Nowadays, shipping economists watch the seaborne trade of China ${ }^{13}$, and of EU, not USA, Japan and Germany, as we did in the past. USA in particular under present 2020 administration adopted a nationalistic policy protecting its own economy from Chinese imports. This was the policy adopted by nations soon after $2^{\text {nd }}$ world war, a policy of national autarky (self-sufficiency) ${ }^{14}$.

The fleets of the top 10 global nations are again shown below (Figure 12).

As shown, 10 global fleets hold $69 \%$ of world carrying capacity, owning about 1.35b GT/DWT out of about 2b GT total, with 27,700 ships of average size: $\sim 49,000$ GT. Greece (as owner, including Greek flag) had the $1^{\text {st }}$ global position with about $18 \%$ share, and $53 \%$ in EU. It carries more than $1 / 5$ of the trade from/to USA and EU.

Most important, however, is that Greece pursued economies of scale as argued all along in this paper with average size $\sim 77,000$ GT, followed by Japan $\sim 59,000$; while China had $\sim 34,000$, and Singapore $\sim 45,000$ (rounded to nearest thousand). As shown, China had many small ships, unlike Hong-Kong having 60,258 GT average fleet size. Greece fixed its fleet with $32 \%$ in tankers, $23 \%$ in bulk carriers, $15 \%$ in LNGs and $15 \%$ in Chemicals (=85/\%).

Above history has provided us with a lot of useful information. But is history repeated (Goulielmos, 2009)? Here we mentioned quite a number of Jokers. Can we predict the appearance of a Joker? Goulielmos (2009: p. 346) predicted that a cycle would start in $14^{\text {th }}$ October, 2008, (not known at that time)... and this was a unique forecasting... which came true.

\section{Cycles in Nonlinear Time Series}

Humans, in their inability to understand complex phenomena, tried to simplify economics by excluding a great part of reality ("reductionism"). Linearity is

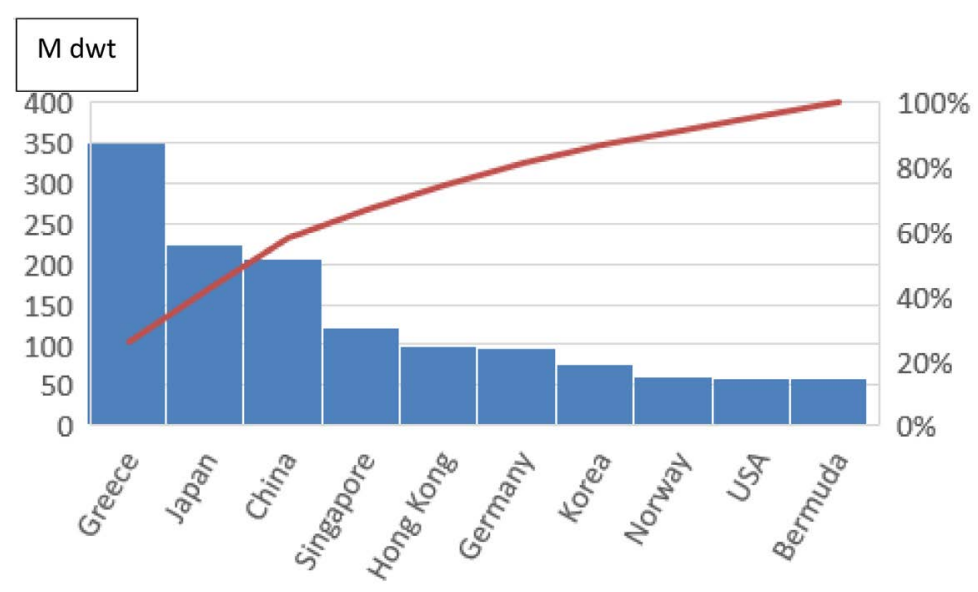

Figure 12. Capacity of 10 global fleets, 2018. Source: Shipping BHMAgazino, issue $149,21 / 06 / 2020$.

${ }^{13}$ BRICS.

${ }^{14}$ Autarky is a situation where a country isolates itself from international trade by restrictions such as tariffs, in an attempt to be self-sufficient, usually for reasons of employment or politics. 
closer to human brain, no doubt, when un-helped by artificial intelligence. This mentality fits exactly to the case of cycles.

For centuries, observers tried to make cycles regular, symmetric-up and -down (Peters, 1994: Chap. 6) and harmonic. Pioneers in this approach were Ancient Greeks-par excellence Euclid, Aristotle, Ptolemy-believing in a divine shape: the circle! They thought that Earth is and "follows" a perfect circle.

Also, Newton, Fourier and Spectral Analysis had the same belief. But this was far away from reality! Stars have an elliptic trajectory for wise reasons. Einstein realized that who constructed Universe made it beautiful, harmonic, and stable, and theories that are not beautiful are wrong... Humans were excluded from such situation to act under absolute... freedom to the extent to disobey also their Father.

People misled by the harmony, accuracy and beauty of the Universe, failed to understand the existence of free will and its implications. Humans behave differently than Universe, which obeys to eternal laws. In shipping, e.g. about 30,000 human decisions make up supply, and about 8 billion human decisions make up demand!

Human decisions for centuries destroyed e.g. global climate. Moreover, humans though they pay the consequences of climatic destruction do nothing to reverse it. Humans contributed also so that everybody to live under an inferior quality. Humans decide freely, and so do business-men, but business-men need par excellence information of what is going-on in order to decide correctly. Technology has been all along at their service. Non sentimental machines, will take all important decisions...?

\subsection{Chaos Theory and Cycles}

Chaos theory showed the existence of nonperiodic cycles and calculated their average duration! Peters (1994: p. 37-38) distinguished cycles in: 1) periodic, and 2) non-periodic. In non-periodic cycles, Peters distinguished 2 of their sources: a) statistical and b) chaotic. The non-periodic cycles have no absolute frequency.

Statistical cycles are found in the "Hurst process", which is a "biased random walk", with no average length. The bias has direction and magnitude. The important issue is that this bias can change abruptly. This is what we meant by Joker-as an exogenous event, not-predictable, in the pack of cards. A random event! Jokers appear also in business life and in maritime economy.

Mandelbrot (1972) studied cycles and argued that their duration is not only a matter of time series, meaning the time passed. Chaotic cycles e.g. can be produced by the "logistic equation", (a simple difference equation of $2^{\text {nd }}$ order), in the nonlinear dynamic systems; these systems are expressed by differential equations. But this logistic equation does not produce the economic or investment cycles (Peters, 1994), we know.

A method, called "Rescaled Range Analysis", can show an existing cycle and its duration (Figure 13). 


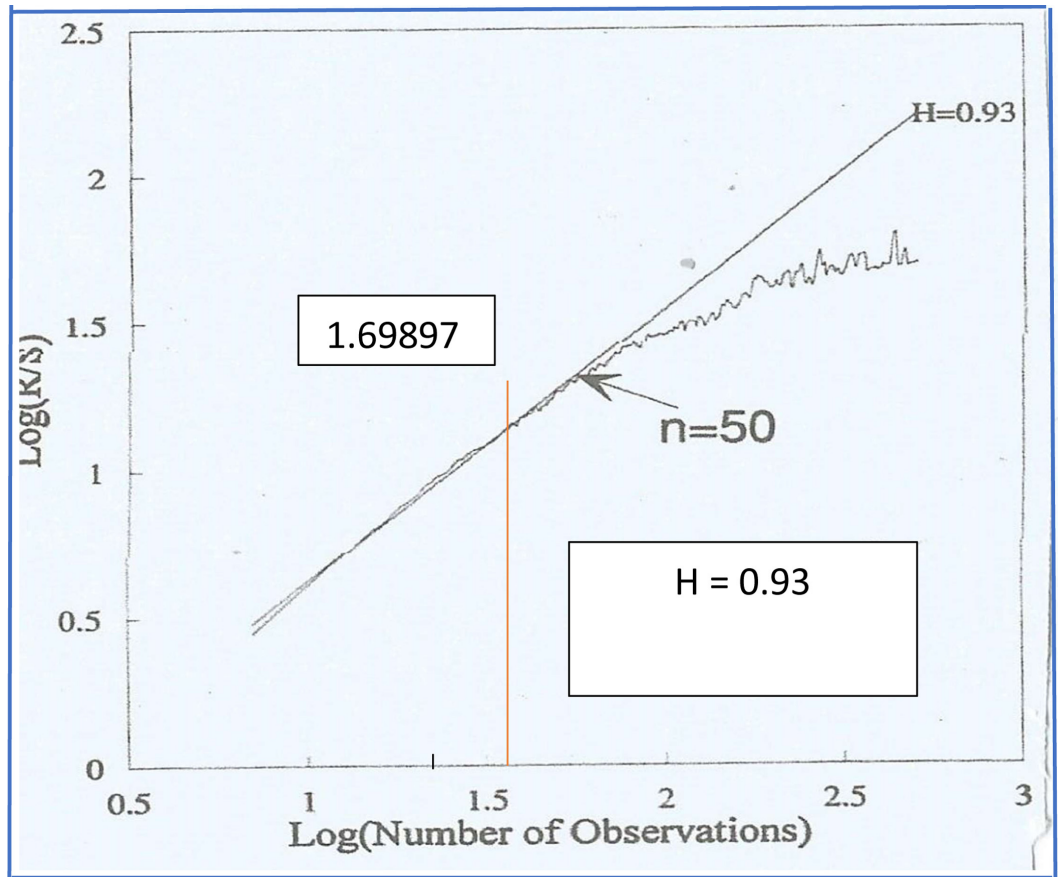

Figure 13. R/S analysis using mackey-glass equation. Source: Peters (1994), p. 98; modified.

As shown, the above equation-presents a smooth deterministic system with high $\mathrm{H}(=0.93 \leq 1)$, and produces a cycle at $\mathrm{n}=50$ observations. Peters argued that stock and bond markets are non-periodic systems, (Granger, 1964; Peters, 1991; Cheng \& Tong, 1992), unlike currencies.

Peters (1994: p. 102) argued also that "Rescale Range Analysis" (Voss, 2013) is able to estimate the length of nonperiodic cycles, as mentioned.

This non-parametric statistical method is briefly presented in Appendix 1. This is due to Hurst (1951) and is a generalization of the one of Einstein, where distance $D$ is equal to the square root of time: $D=\sqrt{\operatorname{time}}\{1\}$, for a particle moving randomly in a stagnant liquid ${ }^{15}$ (Einstein, 1905). Hurst generalized equation $\{1\}$ as follows: let $\mathrm{D}=\operatorname{Range}^{16}\left(\operatorname{rescaled}^{17}\right)=\mathrm{R} / \mathrm{S}$ equal to $\mathrm{c}^{\star} \mathrm{n}^{\mathrm{H}}\{2\}$. If $\mathrm{H}=$ $1 / 2, \mathrm{n}=\mathrm{t}(\mathrm{ime})$, as it is, though discrete, and $\mathrm{c}$ is a constant for time series, then $\{2\}$ reduces to $\{1\}$ (Steeb, 2008). This means that $\{1\}$ holds only when $\mathrm{H}=1 / 2$ or $=0.50=\sqrt{ }$. This critical value of $\mathrm{H}$ exponent (0.5) distinguishes random from non-random time series. Also distinguishes time series in persistent and non-persistent.

Of great importance is when a time series is found persistent, i.e. giving an

\footnotetext{
${ }^{15}$ This was a problem first encountered by Robert Brown in 1828, and remained unsolved till 1905. As a result, the case $\mathrm{H}=0.50=1 / 2=\sqrt{ }$ got the name "Brownian motion" or "white noise".

${ }^{16}$ Range in a time series is the period that comes between maximum $\mathrm{n}$ and minimum $\mathrm{n}$ or mathematically: Range (adjusted) $=\mathrm{Ra}=\max \left(\mathrm{Y}_{1}, \cdots, \mathrm{Y}_{\mathrm{n}}\right)-\min \left(\mathrm{Y}_{1}, \cdots, \mathrm{Y}_{\mathrm{n}}\right)\{3\}$, and so these are made nonnegative (Peters, 1994: p. 56).

${ }^{17}$ Rescaled means divided by local standard deviation S. This genius idea of Hurst freed time series from the dimension of time in the sense that observations in centuries apart, can be compared without the need of time-scale adjustment.
} 
$H>0.50 \leq 1$. In such a case this time series: 1) follow trends; 2) a rise in previous period is most probable to give an increase in next period; 3) they have a long memory/a long-term correlation between present and future, known as black noise (Peters, 1994: p. 310). Moreover, we distinguish time series in faster $(1 \leq$ $H>1 / 2)$ or $\operatorname{slower}(H<1 / 2$ or $\geq 0)$ than random ones $(H=0.5=\sqrt{ })$.

\subsection{Application of "Rescaled Range Analysis" to Shipping Market}

We applied this method to Dry Cargo Market between 1741 and 2012 and we found $\mathrm{H}=0.69>0.5 \leq 1$ (Figure 14) (we took the maximum $\mathrm{H}$ value of the series as this characterizes them, and for $\mathrm{n} \geq 10$ ).

As shown, shipping $\mathrm{H}$ exponent is $0.69>0.50 \leq 1$, and thus freight rate time series for dry cargoes are persistent. Using the same method, we found the duration of cycles, (Figure 15), in the 1sttechnological period, 1741-1852. The cycle duration is indicated at the time the log R/S curve flattens.

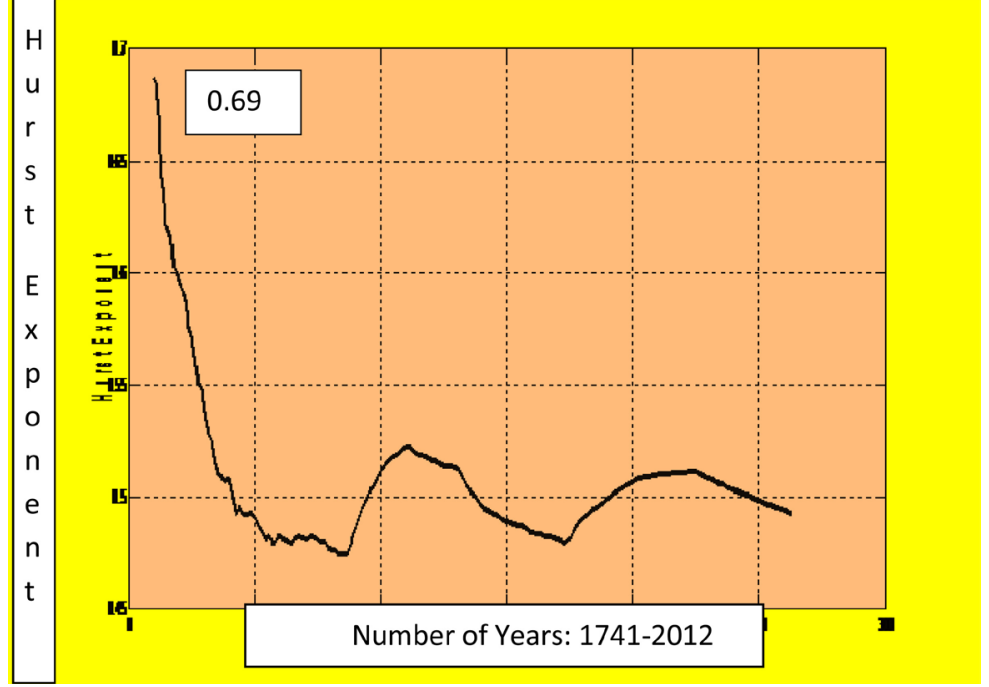

Figure 14. H exponent - dry cargo market, 1741-2012-Yearly. Source: data from stopford; using MATLAB $7.9 \mathrm{v}$.

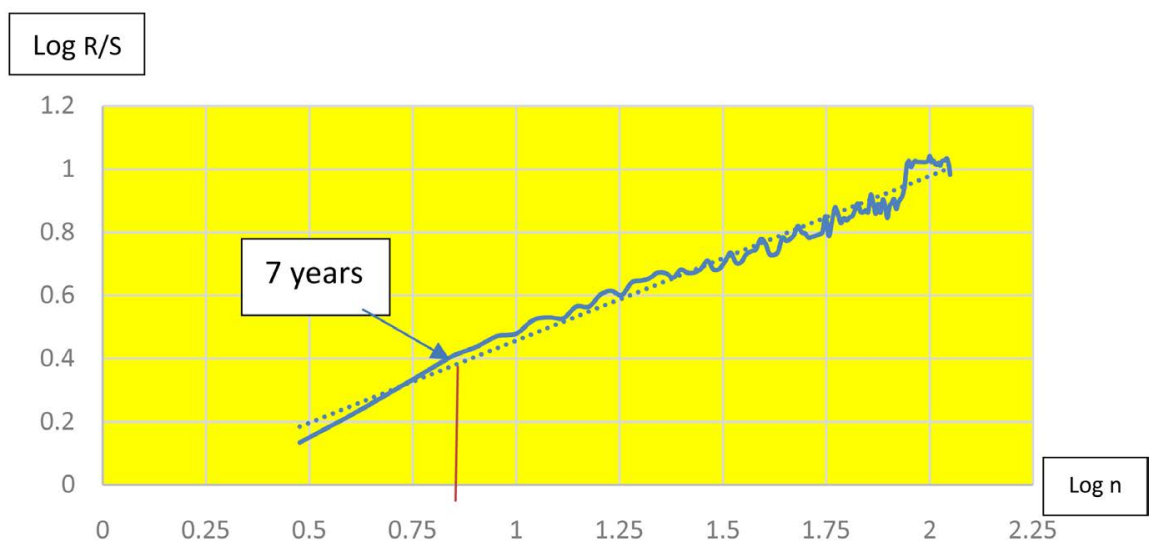

Figure 15. $\log \mathrm{R} / \mathrm{S}$ v. $\log \mathrm{n}, 1741-1852$, freight rates dry cargo cycle for sailing ships. Source: author with data from Stopford, 2009. 
This $1^{\text {st }}$ period, (112 years), shows a cycle at $\mathrm{n}=7$ years (log. 0.84 rounded), where R/S flattened. This is the maximum value after one cycle (Peters, 1994: p. 88; Mandelbrot \& Wallis, 1969). As argued by Peters (1994: p. 92) Rescaled Range Analysis can reveal more clearly existing cycles if these are less than 4.

As shown (Figure 16), now (for 94 years), the cycle during the $2^{\text {nd }}$ technological period is shown at $\mathrm{n}=6$ years ( $\log 0.78$ rounded).

As shown (Figure 17), (for the last 71 years), the cycle is shown at $n=4$ years (log. 0.60).

Cycle duration thus varies from period to period. From 1951 to 2004 we counted 7 cycles diagrammatically with an average duration of almost 7 years. Chaos theory, however, gave an average cycle of 6 (rounded) years. The cycle duration fell since 1741 from 7 years to 4 years! Technology thus, albeit, became a curse and a blessing at the same time... Imagine a shipowner in the 1700s how happy was to scrap his/her vessel, when her technical life coincided with her economic life, at the moment when a shipping cycle begun!

$\log R / S$

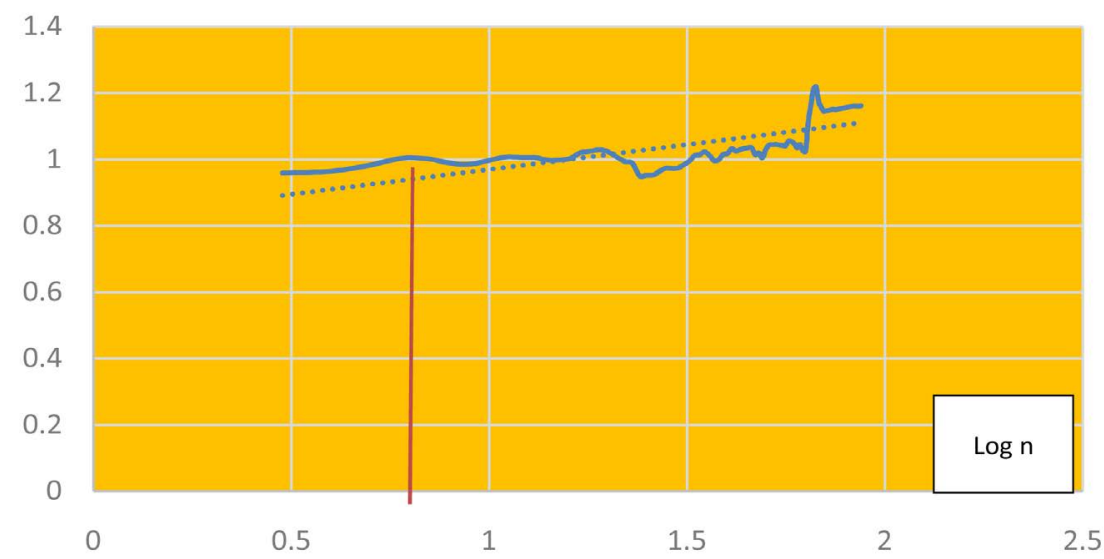

Figure 16. $\log$ R/S v. $\log$ n, 1853-1946, freight rates dry cargo cycle. Source: as in previous figure.

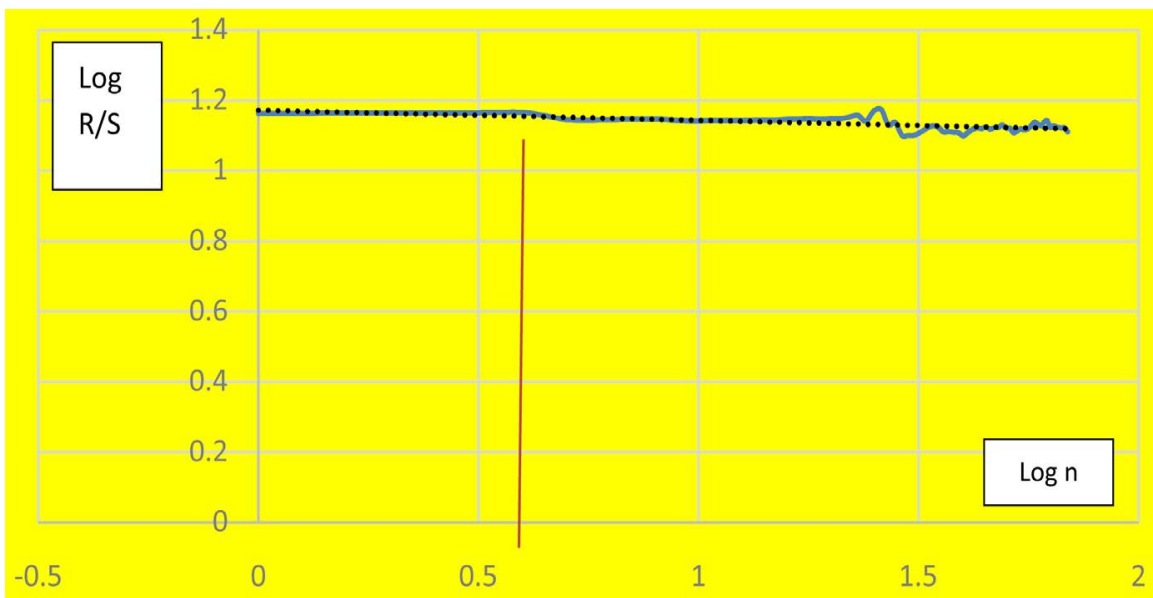

Figure 17. Source: as previous figures. 


\section{Is Shipping Forecasting Possible?}

Goulielmos (2019) used a "nonlinear prediction method", called "radial basis functions", (due to Casdagli, 1989), predicting the value of freight rate index for dry cargoes, and coefficient "alpha"18 for the next 20-years, 2013-2032 ${ }^{19}$.

Many scientists say that Professors when they are making predictions they say: "As I predicted 10 years ago", but only if they were successful...

As shown (Figure 18), the freight market was expected to be at its lowest point in $2019\left(7^{\text {th }}\right.$ year $)$, and in $2032\left(20^{\text {th }}\right.$ year $)$. The Joker will appear in 2022, given the lowest alpha ( 1.16). The shipping cycle is from A to C (2015-2028) lasting 14 years $(\mathrm{ABC})$ ! The freight rate index of dry cargoes will have a decadence of 5 years (2015-2019); and an up-rising of 3 years 2020-2022 and a decadence again of 6 years, 2023-2028. The actual values of the freight rate index for 2013-2015 were 336, 322 and 216. Thus, our prediction was right for only $2015 \ldots$.. So, we concluded that forecasting was unsuccessful...

Greek shipowners who do not trust predictions, when the prices of ships (newly built and $2^{\text {nd }}$ hand ones) are at rock bottom, proceed to build and buy them, larger and newer. After a while, they get rid of older and smaller ships they own (Goulielmos, 2020). Thus, Greek shipowners achieve: 1) Economies of scale; 2) capital cost economies, covering $1 / 2$ the total cost; 3) economies of age and 4) economies of perfect timing (rock-bottom prices). All these 4 economies reward them so that to stay on the top worldwide position, as shown. Random?

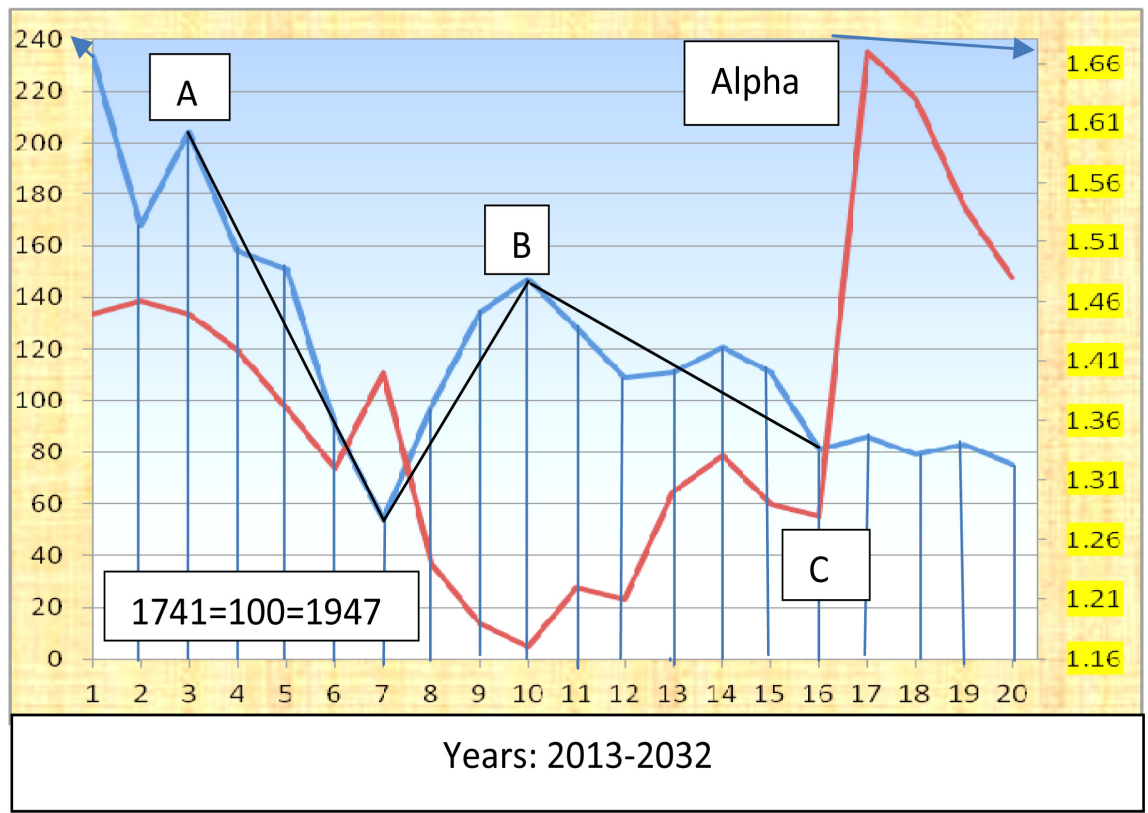

Figure 18. Prediction of dry cargo index and alpha, 2013-2032.

\footnotetext{
18“Alpha" is a measure of how peak is a particular probability density function, meaning also how high is the risk because such distribution has fat tails and so it can deviate $\sigma$ from a maximum $\sigma=3$. Dow Jones e.g. deviated $22 \sigma$ in Black Monday in 1987. "Alpha" of normal distributions is equal to 2. Abnormal distributions show "alphas" equal to 1.00. In 2022 alpha predicted close to 1.16.

${ }^{19}$ The coefficients chosen were: embedding dimension 5 , time delay 1 , relative vectors 16 and $b=1$.
} 


\section{Conclusion}

Shipping time series-as shown beyond doubt-had an intense and frequent cyclicality, since 1741 to 2020 . Their handling, however, was all along wrong, when this attempted by linear statistical methods like "Normal distribution ${ }^{20 "}$ and non-linear "GARCH"21.

Our main conclusions may be summarized in a Table 4 .

The average historical duration of shipping cycles from 1951 to 2020 was 6 years (5.78). Chaos theory gave a cycle duration of 6 (5.67) years on average of a descending duration since 1945 !

It was a sad finding, however, to see that technology instead of improving business life made it worse... by bringing cycles nearer!

The theory of business cycle is indeed confusing: are the 2 semicircles equal? Are bad times equal to good times, or are the former are longer? The facts revealed by the text should not be ignored, however, but shipowners have to be prepared to get advantage of them. We showed them how...

Shipping crises (recessions; depressions) are not in the hands of shipowners exclusively, as many may believe, but shipbuilders help as well! Shipowners

Table 4. A survey of shipping cycles, 1951-2020.

\begin{tabular}{|c|c|c|c|c|c|}
\hline $\begin{array}{c}\text { Cycle's } \\
\text { start }\end{array}$ & End & Duration & Peaks & Troughs & Joker \\
\hline 1951 & 1956 & 6 years & $\begin{array}{l}\text { 1951:1 year } \\
1956: 1 \text { year }\end{array}$ & $\begin{array}{l}\text { 1952-1955: } 4 \\
\text { years }\end{array}$ & $\begin{array}{l}1951 \text { Korean war; } \\
1^{\text {st }} \text { Suez Canal's } \\
\text { closure } 1956\end{array}$ \\
\hline $\begin{array}{l}1967 \\
1970\end{array}$ & $\begin{array}{l}1970 \\
1974\end{array}$ & $\begin{array}{l}4 \text { years } \\
5 \text { years }\end{array}$ & $\begin{array}{l}\text { 1967: } 1 \text { year } \\
\text { 1970:1 year } \\
\text { 1973-1974: } 2 \\
\text { years }\end{array}$ & $\begin{array}{l}\text { 1968-1969: } 2 \\
\text { years } \\
\text { 1971-1972: } 2 \\
\text { years }\end{array}$ & $\begin{array}{l}2^{\text {nd }} \text { Suez Canal } \\
\text { closure the } 6 \\
\text { days war; } \\
\text { The Yom Kippur } \\
\text { war }\end{array}$ \\
\hline $\begin{array}{l}1980 \\
1989 \\
1995\end{array}$ & $\begin{array}{l}1989 \\
1995 \\
2004\end{array}$ & $\begin{array}{l}10 \text { years } \\
7 \text { years } \\
10 \text { years }\end{array}$ & $\begin{array}{l}\text { 1980:5 years; } \\
4 \text { years } \\
1995 \\
2004 \\
200713 \text { years }\end{array}$ & $\begin{array}{l}\text { 1982-86: } 5 \text { years; } \\
\text { 1992-4: } 3 \text { years } \\
\text { 1997-2002: } 6 \\
\text { years }\end{array}$ & $\begin{array}{l}\text { Iranian } \\
\text { revolution. } \\
\text { Iran-Iraq war. } \\
\text { Dot.com. crisis } \\
\text { Kuwait war; } \\
\text { Asian crisis; } \\
\text { China’s boom; }\end{array}$ \\
\hline 2005 & 2008 & 4 years & $\begin{array}{l}\text { 2003-2008: } 6 \\
\text { years }\end{array}$ & & \\
\hline 2009 & 2013 & 5 years & & 2009-13: 5 years & $\begin{array}{l}\text { Sub-prime house } \\
\text { loans crisis } \\
2008-13\end{array}$ \\
\hline 2020 & 2021 & 1 year & & & $\begin{array}{l}\text { COVID-19 } \\
\text { pandemic }\end{array}$ \\
\hline
\end{tabular}

Source: author from text.

${ }^{20}$ Jiang, 2015.

${ }^{21}$ The generalized autoregressive conditional heteroscedastic model. 
order ships, no doubt, and they bear the prime responsibility for it. Shipbuilders, however, offer finance and offer low prices, as the case may be, and faster delivery times. But, they cannot be blamed.

\section{Conflicts of Interest}

The author declares no conflicts of interest regarding the publication of this paper.

\section{References}

American Economic Association (1950). Readings in Business Cycle Theory. London: George Allen and Unwin Ltd.

Casdagli, M. (1989). Nonlinear Prediction of Chaotic Time Series. Physica D: Nonlinear Phenomena, 35, 335-356. https://doi.org/10.1016/0167-2789(89)90074-2

Cheng, B., \& Tong, H. (1992). On Consistent Non-Parametric Order Determination and Chaos. Journal of the Royal Statistical Society: Series B, 54, 427-449. https://doi.org/10.1111/j.2517-6161.1992.tb01890.x

Couper, A. D. (1999). Voyages of Abuse: Seafarers, Human Rights and International shipping. London: Pluto Press.

Cournot, A. A. (1927). Researches into the Mathematical Principle of the Theory of Wealth. New York: Macmillan.

Einstein, A. (1905). A New Determination of the Required, by the Molecule-Kinetic Theory of Heat, Movement of Small Particles Moving inside Stagnant Liquid. Annals of Physics, No. 322. (Title translated by author from German)

Goulielmos, A. M. (2009). Is History Repeated? Cycles and Recessions in Shipping Markets, 1929 and 2008. International Journal of Shipping and Transport Logistics, 1, 329-360. https://doi.org/10.1504/IJSTL.2009.027679

Goulielmos, A. M. (2019). Forecasting the Next Dry Cargo Shipping Depression beyond 2018. Modern Economy, 10, 1684-1712. https://doi.org/10.4236/me.2019.107110

Goulielmos, A. M. (2020). The Investment Strategy and the Growth Policy of Greek Shipowners Revealed, 1946-2020. Modern Economy, 11, 1263-1279. https://doi.org/10.4236/me.2020.117090

Granger, C. W. J. (1964). Spectral Analysis of Economic Time Series. Princeton, NJ: Princeton University Press.

Hurst, H. E. (1951). The Long-Term Storage Capacity of Reservoirs. Transactions of the American Society of Civil Engineers, 116, 770-799.

Jiang, S. (2015). More Evidence against the Random Walk Hypothesis. Singapore: World Scientific. https://doi.org/10.1142/9412

Mandelbrot, B. B. (1972). Statistical Methodology for Non-Periodic Cycles: From Covariance to R/S Analysis. Annals of Economic \& Social Measurement, 1, 259-290.

Mandelbrot, B. B., \& Wallis, J. (1969). Robustness of the Rescaled Range R/S in the Measurement of Noncyclic Long Run Statistical Dependence. Water Resources Research, 5, 967-988. https://doi.org/10.1029/WR005i005p00967

Pearce, D. W. (Ed.) (1992). Macmillan Dictionary of Modern Economics (4th ed.). London: Palgrave.

Peters, E. E. (1991). A Chaotic Attractor for the S\&P 500. Financial Analysts Journal, 47, 55-62. https://doi.org/10.2469/faj.v47.n2.55 
Peters, E. E. (1994). Fractal Market Analysis: Applying Chaos Theory to Investment \& Economics. Wiley Finance Edition, Hoboken, NJ: Wiley.

Schumpeter, J. A. (1954). History of Economic Analysis. London: Allen \& Unwin.

Steeb, W.-H. (2008). The Nonlinear Workbook ( $4^{\text {th }}$ ed.). Singapore: World Scientific. https://doi.org/10.1142/6883

Stopford, M. (2009). Maritime Economics (3rd ed.). London: Routledge. https://doi.org/10.4324/9780203891742

Voss, J. (2013). Rescaled Range Analysis: A Method for Detecting Persistence, Randomness or Mean Reversion in Financial Markets. http://blogs.cfainstitute.org/investor/2013/01/30/rescaled-range-analysis-a-method-for -detecting-persistence-randomness-or-mean-reversion-in-financial-markets/

\section{Appendix}

Appendix 1: Rescaled Range Analysis (Peters, 1994: p. 55 and thereafter; Steeb, 2008: p. 96 and thereafter).

Assume that we have a time series $x:=x_{1}, \cdots, x_{n}\{1\}$ with $\mathrm{n}$ consecutive values. Because time series are transformed into stationary, we use first logarithmic differences, $r=n-1$. We need also the mean of the series, i.e. sum divided by $n$. We need also the standard deviation of $n-1$ series. Rescaled range is calculated by first "normalizing" data by subtracting the mean. Einstein (1905) proved that $\mathrm{D}=\sqrt{\text { time }}\{2\}$. Hurst (1951) found a more general formula including $\{1\}$ as a special case: $D=c * n^{k}\{3\}$, where $\mathrm{c}$ is a constant and time $=\mathrm{n}$ (number of observations over time), $k$ is a power receiving values from [0 to 1] and for honor to Hurst $k=H$ (root of time); $D=$ Range (rescaled) indicating distance by subtracting from maximum value the minimum value. Thus: $R / S=c * n^{H}\{4\}$. Einstein's formula comes if $D=R / S, n=t$ and $k=1 / 2$. For practical reasons: we take $\log$ of $\{4\}$ and get $\log (R / S)=\log c+H \log n\{5\}$. The values of $H$ in the above closed interval characterizes time series as persistence, anti-persistence and random. $S$ is local standard deviation. 